摘

\section{要}

1. カンキツ黒筹病の発病進展速度は，果実のクエン 酸含量が高いほど遅く，本試験では，病徎発現曰数，発 病率 100\% 亿達する日数は, クエン酸含量 $1 \mathrm{~g} / 100 \mathrm{ml}$ 以 上でそれぞれ 4 日，30日以上， $1 \sim 0.7 \mathrm{~g} / 100 \mathrm{ml}$ で $1 \sim$ 2 日，21〜28日，0.7 g/100ml 以下で 1 日，12日であっ た。
2. 貯蔵中の発病と果実のクエン酸含量との間にはか なり高い相関が認められ，クエン酸含量が少ないほど発 病率は高い。しかし，クエン酸含量 $1 \mathrm{~g} / 100 \mathrm{~m} l$ 前後で発 病率にかなりのふれがみられたため, さらに他の貯蔵要 因についての検討が必要と思和机た。

\section{引用文献}

1）小野公夫(1973) 九病虫研会報 19：46-49.

\title{
Alternaria 属菌によるカンキッそうか病様症状の発現
}

$\begin{array}{llll}\text { 小 } & \text { 野 } & \text { 公 } & \text { 夫 (長崎県果樹試験場) } \\ \text { 富 } & \text { 尾 } & \text { 孝 } & \text { 雄 (佐世保病害虫防除所) }\end{array}$

1974年 5 月上旬，発生予察の巡回調查中，北松浦郡江 迎町の温州ミカン園の春葉に，カンキツそうか病にきわ めて良く似た症状が多発しているのを見出した。症状の 特徽は，初期に発症部がやや突起し，その周囲に淡黄色 のハローがみられる。その後，葉が硬化するにしたがっ て突起が顕著となり，さらに甚しい場合は葉か湾形した り穴があくなどの症状を呈した。このため，佐世保病害 虫防除所管内でその症状の発生状況を調査したところ， 程度は軽いが，かなり多くの園でも発生していることが 判明した。さらに1975年の観察でも各地で同じような症 状の発生が見られたため,これについて再現試験を行っ たのでその結果について報告する。

\section{試 験 方 法}

1. 接種方法

1）ピン接種：昆虫 1 号針で葉㧍よび果実に刺傷を与 え，付傷部に胞子懸濁液をしませた脱脂綿を置いて行っ た。葉の刺傷に際しては貫通しないように留意した。な お，付傷部の湿度を保つため，接種葉はビニールで 1 夜 覆った。2）カーボランダム接種：脱脂綿に殺菌水を 含ませ，カーボランダムを少量着けて輅く禁の上を 1 回 なでて付傷後、ピン接種と同じ処理で接種した。

2. 供試胞子浱度 ッアペック寒天上に形成させた胞 子を用い，葉に対する試験では，顕微鏡 150 倍 1 視野 10 ～15個，果実の場合は，150倍 1 視野50１00個程度の胞 子懸濁液汇調整した。

3. 調查方法 接種 7 ～10日後に発症および反心の有 無を調查した。

4. 試験規模 1 処理 6 葉(果)を供試し， 1 葉(果)当 たり 3 カ所に接種した。

5. 供試葉, 果実 供試葉は 2 年生温州ミカンを強く
せん定して発芽させたものを，果実は20年生温州ミカン のを用いた。

\section{試験 結果と考察}

1. 症状部位分らの分離菌倸よる再現 症状部分ら菌 の分離を行い，再現を試みた。分離菌株梳第 1 表のとお りで,このうち，春菜に反応を示し，さらにその中で， そうか嘊樣症状の反応を示したのは Alternaria sp. だ けであった。なお，分離菌株の Alternaria sp. 1〜10 は同じ反応を示したので以後の試験には Alternaria sp. 1 を供試した。また, Alternaria sp. 1 をミカン 果契に接種したところ A . citri と同㥞の笍敗を起した。 そのため, 長崎県果樹試験場保存している A. citri 株を用いて，春葉の反応をみたところ Alternaria sp. 1 と同じようにそうか病㥞症状を示した。

第 1 表，症状部位加 万の分離菌による反応 ('75.3.20 江迎町の発症葉)

\begin{tabular}{|c|c|c|}
\hline 分 離 菌 株 & $\begin{array}{l}\text { 春葉に対す } \\
\text { 辰 }\end{array}$ & $\begin{array}{l}そ う か 2 \text { 病樣 } \\
\text { 症状の発現 }\end{array}$ \\
\hline Alternaria $\mathrm{sp.} 1 \sim 10$ & + & + \\
\hline Fusarium sp. 2 & + & - \\
\hline Phomopsis sp. & - & - \\
\hline Cercospora sp. & - & - \\
\hline Colletotrichum sp. & - & $\rightarrow$ \\
\hline Phoma sp. & - & - \\
\hline Pestalozzia sp. & - & - \\
\hline Botryt is sp. & - & - \\
\hline Aspergillus sp. & - & - \\
\hline Penicillium sp. & - & - \\
\hline Bacteria ( 7 菌株) & - & - \\
\hline Alternaria citri & + & + \\
\hline
\end{tabular}


第 2 表 Alternaria sp. の時期別分離状沅 (江迎町)

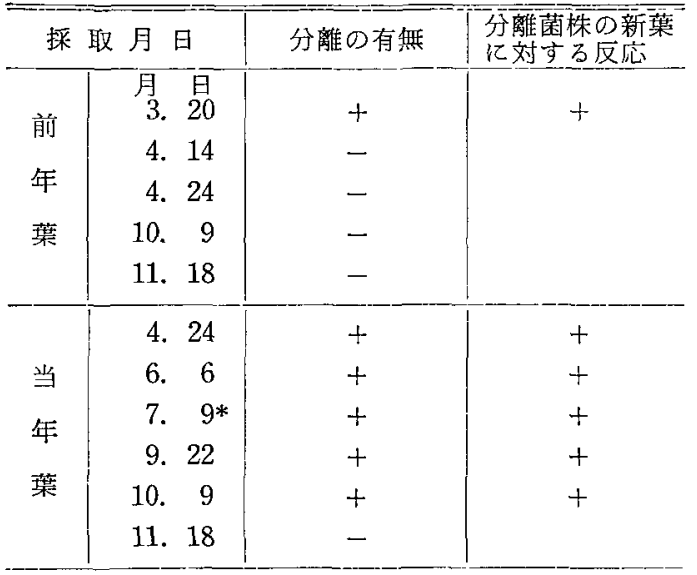

*誎早市長田

2. Alternaria sp. の時期別接程及び分䧺状沉

Alternaria sp，でそうか病槉症状の再現が可能であ るため，Alternaria sp. の時期別接種および分離を試 み, 感染可能な時期と症状部での菌の生存状態を検討し た。

発症園加らの採取葉化上る Alternaria sp. の分離状 洗は第 2 表のとおりである。こ扎でみると，前年葉から 分離できたのは 3 月20日採取葉のみで，その他の時期は 分離できなかった。当年葉は10月 9 日採取葉までは分離 できたが，その後は分離できなかった。このことから，
Alternaria sp. はそうか病様症状を発現した後，症状 部位ではあまり長期閒生存できないのではないかと思わ 扎る。なお，分離株は，接種，再分離して，葉に対する 病原性を碓認できた。

時期別接種に上る再璁状況は第 3 表のと挔りである。 接種に用いた清葉は，4月中旬発芽した 2 年生普通鼬州 ミカン葉を継続して用いた。したがって，4月17日は発 牙直後で，5月16日は硬化直後である。な㧍，4月17日 のピン接種区とカーボランダム接種区は落葉したため症 状の発現か碓認できなかった。

展開葉（4月26日）から硬化面後葉（5月26日）まで はピン接種区のみが症祀を発現し，その後，6月14日の 硬化葉に対する無傷接種区でチョコレート色の斑点症状 の発現がみられた。このチョコレート色の斑点症状は江 迎町のほ場でもかなりの発生を認めている。

なお，A. citriについても同様の接種を行いAlternaria sp. と同じ反応を示すことを確諗した。

3. Alternaria sp. 接種による舆実の泟状 果実で の Alternaria 属菌による反応としては, 禧久”によって がさ症が，含本 ${ }^{2}$ によって小黒点症が報告されている。 春葉でのそうか病様証状を芫出した江迎町のほ場でも果 実の小黑点症の発生が多かったため, 果或に Alternaria sp. 1 とA. citri を接種して，その反応在検討した。第 4 表に示すとおり，7月25日までは，Alternaria sp. 1 とA. citri ともがさ症粏が，8月8日は A. citriで， 10月29日は Alternaria sp. 1 とA. citri とも小黑点

第 3 表 時 期 別 接 種による 再 現（春葉）

\begin{tabular}{|c|c|c|c|c|c|c|c|c|c|c|c|c|c|c|c|c|c|c|c|c|c|}
\hline 月・日 & & 4.12 & & & 4.2 & & & 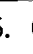 & & & 5.1 & & & 5. 2 & & & 14 & & & 6.27 & \\
\hline 接種源 接種法 & $\mathbf{P}$ & $\mathrm{C}$ & $\mathrm{N}$ & $P$ & $\mathrm{C}$ & $N$ & & 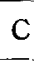 & $N$ & $P$ & & $\mathrm{~N}$ & $\mathrm{P}$ & $\mathrm{C}$ & I & & & & $P$ & $\mathrm{C}$ & $\mathrm{N}$ \\
\hline A. sp. 1 & & & + & $H$ & 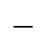 & - & H & - & 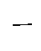 & H & & - & - & 一 & & & & & - & - & - \\
\hline A. citri & & & H & $H$ & - & - & \# & - & - & H & - & - & - & - & & $\tau$ & - & 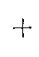 & - & - & - \\
\hline Dist. water & - & - & - & - & - & - & - & - & - & - & - & - & - & - & - & - & - & - & - & - & - \\
\hline
\end{tabular}

$\mathrm{P} ：$ 舁虫 1 号針による付傷接種

$\mathrm{C} ：$ カーボランダム "

$\mathrm{N}$ ：無 傷

第 4 表 時 期 別 接 種 $よ$ 再 現 (果夷)

\begin{tabular}{|c|c|c|c|c|c|c|c|c|c|c|c|c|c|}
\hline \multirow{2}{*}{ 接種源 } & \multicolumn{3}{|c|}{ 6. 14} & \multicolumn{3}{|c|}{ 6. 27} & \multicolumn{3}{|c|}{ 7. 25} & \multicolumn{3}{|c|}{ 8. 8} & \multirow{2}{*}{ 10. 29} \\
\hline & $\mathrm{P}$ & $\mathrm{C}$ & $\mathrm{N}$ & $\mathrm{P}$ & $\mathrm{C}$ & $\mathrm{N}$ & $\mathrm{P}$ & $\mathrm{C}$ & $\mathrm{N}$ & $\mathrm{P}$ & $\mathrm{C}$ & $\mathrm{N}$ & \\
\hline A. sp. 1 & - & + & - & - & + & - & - & + & - & - & - & - & $H$ \\
\hline A. citri & - & + & - & - & + & - & - & + & - & - & - & $H$ & H \\
\hline Dist, water & - & - & - & - & - & - & - & - & - & - & - & - & - \\
\hline
\end{tabular}

十：がさ症状 H：黒点症状 
症の発現が認められた。

以上のように，江迎町で見出したそうか病様症状は再 現試験の結果, 症状部から分離されたところの Alterna： ria sp. Kよっておこると考えられる。また，その感染 期間は，春菻では発芽初期から5月中旬，果実では，が さ症の場合 6 月から 7 月下旬まで，小黒点症は 8 月以後 と思われる。

\section{摘}

要

1. 春葉でのそうか病样症状は再現試験の結果, 症状 部加分離された Alternaria sp. によるものと思われ
る。

2. Alternaria sp. の接種による症状は春葉の場合, 発芽初期から 5 月中旬まではそうか病様症状を，6月中 句ではチョコレート色斑点症状を示し，果実の場合，6 月から 7 月下旬まではがさ症状を，10月では小黒点症状 を示した。

\section{引用文献}

1）禧久保 - 河野通昭 (1971) 九病虫研会報 17: 4 7.

2）倉本孟 (1974) 果樹試與津年報(病 - 虫) 2: 45 47.

\title{
カンキッの果頂部褐変症（仮称）に関する研究 第 1 報 タンカンにおける症状と発生
}

\author{
長 浜正照（鹿児島県果樹試験場）
}

タンカン (Citrus tankan HAYATA) は年平均気温19 ${ }^{\circ} \mathrm{C}$ 以上の温暖なところが栽培適地であり，わが国では鹿 児島県南部と宮崎県, 高知県の一部で栽培されている。 このタンカンにここ $2 \sim 3$ 年来, 果頂部の褐変する症状

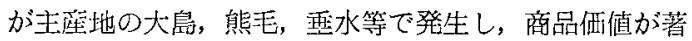

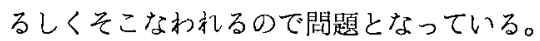

筆者は果頂部䙓変症について検討しているので，今回 はタンカンにおける症状と発生について得た知晃を報告 する。

\section{1. 発 生 の 概 況}

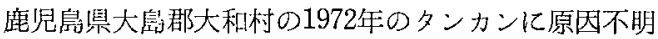
の外観阻害果が異常に多いことから問題となったもので， 1972年以前にも発生は観察されている。

鹿先扁孯のタンカン主要産地における発生状沅は第 1 表に示すとおりで， 3 カ年を通じての発生は，本土と種 子島地域では比較的少ないが，大島地域では多く，特に 大島の一部の園では全果発生という状沉のところもあり， タンカンの外歓に著るしい影響を及玨している。

\section{2. 症}

\section{状}

初期症状は1975年の锶察結果によると，当初，果顶部 に輪隔のはっきりしない灭色の大小の斑点が兒われここ の斑点にははじめ小黒点肪点在していた。やがて，この 小黒点から龟裂を生じ，亀裂が增加するにしたがい，果 皮は褐变して本䋊に進展するもののようである。

本症発生果は一見してミカンサビダ二の被邫果に似て おり，ふつうの場合, 柱頭あとを中心に果顓部周边の果
第 1 表 各産地での発生状沇

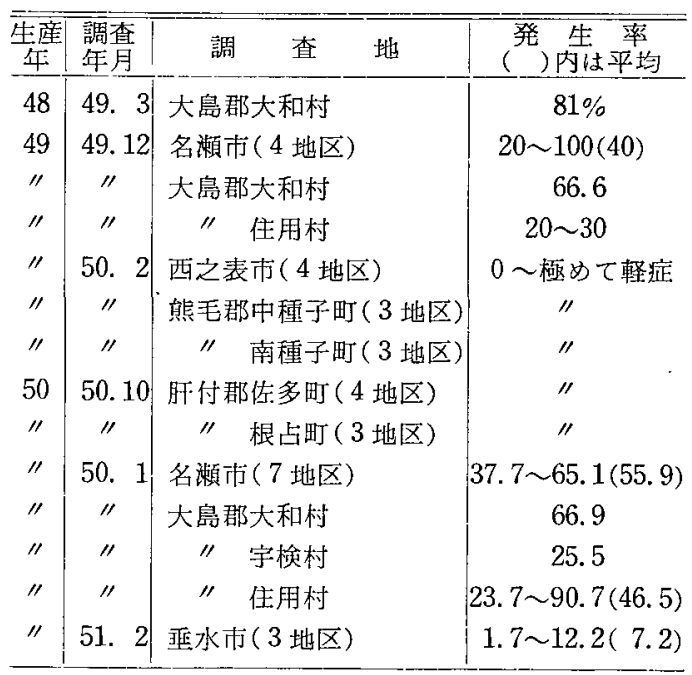

皮面に無数の微細な龟裂が自られ，果皮は粗く，踾を失 って褐変している。症状が著るしく進行すると䘽変部分 が果面全体に及ぶこともある。

本症に類似の症状として, ミカンサビダニの被害，そ ばか寸病，マシン油乳剂の薬害等があるが，本症がミカ ンサビダニの被彗, マシン油乳剂の薬㕩でないことは確 認した。

\section{3. 発 生 消 長}

1974年に本症の発生を認的た重水市本城目果樹試験場 内のタンカン14年生樹抢よび垂水市蛸迫現地ほ場のタン 